https://helda.helsinki.fi

Policy or person? : The electoral value of policy positions and personal attributes in the Finnish open-list system

von Schoultz, Åsa

2021-07-01

von Schoultz , Å \& Papageorgiou , A 2021 , ' Policy or person? The electoral value of policy positions and personal attributes in the Finnish open-list system ' , Party Politics, vol. 27 , no. 4 , 1354068819891048 , pp. 767-778 . https://doi.org/10.1177/1354068819891048

http://hdl.handle.net/10138/333270

https://doi.org/10.1177/1354068819891048

acceptedVersion

Downloaded from Helda, University of Helsinki institutional repository.

This is an electronic reprint of the original article.

This reprint may differ from the original in pagination and typographic detail.

Please cite the original version. 


\section{Party Politics}

\section{Policy or person? The electoral value of policy positions and personal attributes in the Finnish open-list system}

\begin{tabular}{|c|l|}
\hline Journal: & Party Politics \\
\hline Manuscript ID & PP-2019-0157.R2 \\
\hline Kanuscript Type: & Article \\
\hline Keywords: & $\begin{array}{l}\text { Open-list proportional representation, Intraparty competition, Personal } \\
\text { characteristics, Policy positions }\end{array}$ \\
\hline Abstract: & $\begin{array}{l}\text { Under open-list proportional representation (OLPR), individual candidates } \\
\text { compete for personal votes and representation has a distinctly } \\
\text { individualistic dimension. This manuscript provides a unique analysis of } \\
\text { this individualistic representational dimension, by comparing the effects } \\
\text { of policy positions with personal vote-earning attributes (PVEA) on } \\
\text { individual electoral success within the context of the Finnish OLPR. The } \\
\text { study confirms that personal attributes related to experience, locality } \\
\text { and celebrity status have a strong positive effect on candidates' ability to } \\
\text { attract personal votes. On a more novel account it also demonstrates } \\
\text { that even under decidedly complex electoral settings, policy positions } \\
\text { matter for candidates' electoral fortunes, and that candidates who take } \\
\text { on moderate positions within the context of their respective party are } \\
\text { more successful than candidates who deviate from the party-median. }\end{array}$ \\
\hline
\end{tabular}

\section{SCHOLARONE" Manuscripts}




\title{
Policy or person? The electoral value of policy positions and personal attributes in the Finnish open-list system
}

\author{
Under open-list proportional representation (OLPR), individual candidates compete for \\ personal votes and representation has a distinctly individualistic dimension. This manuscript \\ provides a unique analysis of this individualistic representational dimension, by comparing the \\ effects of policy positions with personal vote-earning attributes (PVEA) on individual \\ electoral success within the context of the Finnish OLPR. The study confirms that personal \\ attributes related to experience, locality and celebrity status have a strong positive effect on \\ candidates' ability to attract personal votes. On a more novel account it also demonstrates that \\ even under decidedly complex electoral settings, policy positions matter for candidates' \\ electoral fortunes, and that candidates who take on moderate positions within the context of \\ their respective party are more successful than candidates who deviate from the party-median.
}

Keywords: Open-list proportional representation, intraparty competition, personal characteristics, policy positions 


\section{Introduction}

Under electoral systems with preferential voting, representation is not constituted solely by the link between voters and political parties as collective actors. Since votes are cast for individual candidates, and candidates depend on their ability to attract preference votes in order to become elected, representation has a distinctly individualistic dimension. This manuscript provides a unique analysis of this individualistic representational dimension, by comparing the effects of policy positions and personal vote-earning attributes (PVEA) on individual electoral success under openlist proportional representation (OLPR).

At an overarching level, theories of voter's electoral behaviour and the strategies applied by candidates, can be grouped into two different categories: those related to the political message, and those that revolve around the carrier of the message. Generally, high levels of intraparty competition are expected to depress the value of the political message and increase the currency of personal attributes, since voters tend to be more responsive to simple cues under highly complex information-settings (Lau and Redlawsk 2006). Under OLPR, where many candidates are available, voters are expected to use the personal characteristics of candidates as heuristic devices that influences their choice of candidate (Shugart et al. 2005; Valdini 2006). The literature on intraparty competition clearly supports this; demonstrating the electoral value that personal vote-earning attributes such as experience, localism and celebrity status exhibit (Shugart et al. 2005; Put and Maddens 2015; Tavits 2010).

Turning to the substantive part of the representational link, the literature on electoral systems suggests that preferential voting systems, such as OLPR, does not incentivise candidates to pursue the median voter, but rather to adopt a strategy which allows them to carve out an individual basis of support, and to target discrete voter cohorts (Matakos et al. 2018; Shugart et al. 2005; Carey and Shugart 1995; Ames 1995; Cox 1990). This tendency is further supported by the incentives for parties to field candidates with diverse opinions in order to reach as many potential voters as 
possible (Kitschelt and Smyth 2002). Overall, this leads to the expectation that electoral systems with multimember districts and preferential votes, such as OLPR, undermine the ideological cohesion of parties (Kitschelt and Smyth 2002; Carey 2007), and that candidates who adopt distinct policy positions compared to their co-partisans are more electorally successful than partymoderates. Proximity theory, on the other hand, informs us that voters seek candidates (and parties) that are ideologically close to their own positions (Downs 1957), speaking towards greater success for candidates that take on party-moderate policy positions.

Empirically speaking, mapping the electoral value of policy positions and personal voteearning attributes is very much unexplored territory. This study fills the gap in the extant scholarship having systematically tested both within the context of the Finnish OLPR. The research include the exploration of over 1,000 candidates nominated in the 2015 parliamentary election and is based on a unique combination of data: a database on candidates' personal characteristics and data on political platforms of candidates derived from voting advice applications (VAA). The extent to which the electoral success of individual candidates is determined by their personal voteearning attributes, and by their policy positions, is evaluated using a three-level mixed generalised linear analysis to account for candidates competing for votes within distinct lists and districts.

The analyses demonstrate that even under substantially complex electoral settings, policy positions do matter for candidates' ability to attract personal votes, and that candidates that take on party-moderate policy positions are more successful than candidates deviating from their copartisans. These findings bring new information regarding the representational link under OLPR and other preferential voting systems with multimember districts.

The following outlines in detail the theoretical points of departure related to the vote-earning strategies of candidates and the decision-making strategies of voters, which led to the specification of the hypotheses. The article proceeds with a presentation of both the empirical setting and the 
research design, before outlining the empirical findings. Finally, the conclusion discusses the implications of the findings for future scholarship.

\section{Intraparty competition under preferential voting systems}

As noted by Carey and Shugart (1995) in their agenda setting study, preferential voting systems with multimember districts are characterised by a high degree of competition on the intraparty dimension; a systemic feature that provides candidates with incentives to cultivate a personal reputation and appeal directly to voters. Elections under these conditions are fought within, as well as between, parties. At the national level, competition tends to revolve around parties as collective organisations and their efforts to attract votes and to maximise seats. At the district level, the competition is as, or more, intense on the intraparty dimension, when candidates running for the same party compete for votes.

While competition on the interparty dimension has attracted substantial attention from scholars interested in electoral systems, the literature on the intraparty dimension has only developed in recent years (Colomer 2011; Bergman et al. 2013). This relatively literature has explored various aspects of the competition between candidates and its effects. For example, studies have targeted the personal attributes that contribute to individual electoral success under various conditions (Shugart et al. 2005, Tavits 2010; Berggren et al. 2010; André et al. 2014; Put and Madden 2015), the effects of preference voting on legislative behaviour (Tavits 2009; Crisp et al. 2013) and on political promotion (Folke et al. 2016; André et al. 2017; Meriläinen and Tukiainen 2018).

Under preferential voting systems with multimember districts, candidates cannot compete solely on the basis of party reputation; with several other candidates in the running, the party label loses its power as a means of differentiating between candidates nominated by the same party. For vote-maximising purposes, candidates thus attempt to cultivate a personal reputation by 
demonstrating distinctiveness from their co-partisans (Matakos et al. 2018; Shugart et al. 2005). The more crowded the list of co-partisans competing for the same seats under the open list is, the greater the incentive becomes to cultivate individual relations to voters (Carey and Shugart 1995; Crisp et al. 2007; André and Depauw 2014).

\section{Personal appeals - the carrier of the message}

The literature has convincingly demonstrated that candidates, in systems that pit co-partisans against each other, use personal vote-earning attributes as a means to cultivate a personal vote and to attract personal followers (Shugart et al. 2005). These PVEA come in different forms but are personal characteristics related to the individual politician, i.e. the carrier of the message, rather than the political message itself.

One of the most established findings in the literature on preferential voting systems is the electoral value of locality, i.e. being "from around here" and having a record of service to the local community (Shugart et al. 2005; Tavits 2010; Put and Maddens 2015; Saarimaa and Tukiainen 2016). Locality functions as a significant short-cut for voters and is generally considered as a proxy for "knowing the area and its interests", and local level incumbency is similarly a valuable proof of political experience. Studies confirm that votes for individual politicians tend to be geographically clustered around their hometown (for a classical example see Key 1949), and politicians with local ties have been found to be more focused on the needs of their locality than non-locals (e.g., Carozzi and Repetto 2016). In the Finnish setting the locality tend to be important, with 60 percent of candidates elected in 1999-2015 being native to the district and close to 73 percent elected to local office within their district (von Schoultz 2018).

Another recognised personal vote-earning attribute, and one frequently discussed in dubious terms, is that of public recognition established by a candidate prior to entering the field of politics (Marshall 1997; Karvonen 2010; Arter 2013). These candidates are commonly labelled celebrity 
candidates, signifying that they are well known from other areas of public life, for example, media or sports, which is generally considered an advantage in the electoral arena (Carey and Shugart 1995; Horiuchi, Smith and Yamamoto 2018), not least for rookies (Arter 2009). While namerecognition is considered the most valuable trait of being a celebrity, voters might connect other qualities to candidates of this type, such as an outsider perspective (Horiuchi et al. 2018). In the Finnish setting around 2 percent of nominated candidates tend to be celebrities (von Schoultz 2017), and these candidates have higher prospects of becoming elected than the average candidate (von Schoultz 2016).

A more established theory is that of the incumbency advantage. A long line of studies, dominantly from the US (Erikson 1971; Gelman and King 1990; Butler 2009), but lately from proportional electoral systems (Kotakorpi et al. 2017; Dahlgaard 2016), have demonstrated the tangible electoral returns from holding office, both from an inter and intraparty perspective. Incumbency signals valuable political experience, and contributes with name recognition (Carson, Engstrom and Roberts 2007). During the period 1962-2011, 85 percent of Finnish MPs ran for reelection, of which 76 percent managed to renew their seat (Karvonen 2014).

\section{Policy appeals - the message}

While proportional representation (PR) is associated with ideologically cohesive parties (Grofman 2008), the open list component is generally considered to weaken party cohesion (Kitschelt and Smyth 2002; Hix 2004; Tavits 2009; Crisp et al. 2013). Carey (2007) identifies competing principals as the underlying mechanism to this tendency. While candidates under closed list PR (CLPR) are dependent only on the party for re-election, preferential voting provides legislators with dual principals, with parties controlling access to the ballot, and voters the chances of becoming elected (Tavits 2009). The direct representational link to voters under these systems provides candidates with more freedom to act according to their personal agenda, and makes them reliant on 
their ability to respond to the demands of voters (Tavits 2009).

The tendency of the open list to undermine ideological cohesion, is also fuelled by the potential party level gains that an ideological dispersed list can bring about. By nominating candidates with diverging policy positions, parties expect to reach a greater diversity of voters and increase their overall vote share (Kitschelt and Smyth 2002; Matakos et al. 2018). Furthermore, parties have strong incentives to invite independent candidates with a large personal following (Cain et al. 1987; Tavits 2009).

The need for candidates to appeal directly to voters under OLRP is hence assumed to generate weaker parties, by pushing the party collective agenda further back on the agenda of individual politicians (Carey and Shugart 1995; Carey 1997). Concomitantly, candidates with a need for carving out a distinct profile, and to appeal to discrete voter cohorts, can be expected to adopt policy positions that set them apart from co-partisans (Matakos et al. 2018; Shugart et al. 2005; Ames 1995).

\section{Bringing in the voters - proximity voting and the usefulness of simple cues}

The above research trajectories show how candidates under OLRP need to cultivate a personal reputation in terms of the personal vote-earning attributes they carry, or by the policy appeals they make, to attract personal votes in competition with their co-partisans. However, the literature on the behaviour of voters suggests that both strategies are not equally effective. Research on voting behaviour further leads us to believe that it is not necessarily distinctiveness in terms of policy positions that makes a candidates successful.

According to the classical version of spatial theory of voting, the proximity model (Downs 1957), a rational voter will choose a candidate (or a party) that most closely aligns with his or her preferences. Translated to a context of intraparty competition, this would imply that voters choose candidates (within parties) that closest reflect their ideological position. While the proximity model 
has been criticised and challenged (e.g. Rabinowitz and Macdonald, 1989), a large number of studies have demonstrated the relevance of ideological distance in understanding vote choices (e.g. Blais et al., 2001; Singh 2010). The assumptions made by the proximity model are not well aligned with the expectations regarding candidate behaviour presented above, i.e. that candidates under high levels of intraparty competition benefit from carving out a distinct profile and hence deviating from their co-partisans in terms of policy position. Rather, it leads us to expect that candidates that position themselves close to the median position within the context of the party they are running for, will win more votes.

As Singh (2010) has demonstrated, however, the likelihood of voters to vote proximately, decrease with the complexity with the electoral environment; a finding that is in line with research on voters decision-making processes that since long has established that voters rely on information shortcuts to assist them in their electoral choice (Popkin 1991; Mondak 1993). Such heuristics are believed to not only increase voters' cognitive efficiency and help them overcome limitations in information processing, but also to reduce the time and effort devoted to deciding how to vote (Lau and Redlawsk 2006). As the level of complexity increases, voters tend be more responsive to simple cues, allowing them to reduce the time and effort devoted to deciding how to vote.

A preferential voting system with multimember districts indeed implies a very complex choice set-up for voters, since they are expected to consider two main factors when deciding how to cast their vote: the (implicit) choice of party and the (explicit) choice of candidate. Making things even more complex, the number of available alternatives on the intraparty dimension tend to be very high. Since voting decisions based on policy positions are highly demanding in terms of information processing (Lau and Redlawsk 2006), the incentives for voters to gathering this type of information in a systematic manner can be expected to be very low. Instead, the typical voter is likely to determine which candidate best matches their preferences, using the least costly method (Valdini 2006). 
Hence, there are valid arguments that voters under such complex vote-settings, use the personal attributes of candidates as information shortcuts to assist their vote choice. Due to the higher costs involved with processing information on ideological and policy positions, these factors are expected to be of lower importance in explaining the electoral choices made by voters.

Consequent upon a rigorous consideration of the above discussion, we generate four hypotheses, of which two are competing. These hypotheses are subsequently tested in the empirical exploration that follows:

H1: Candidates' personal vote-earning attributes related to experience, locality and celebrity status increase their ability to attract personal votes.

H2: Candidates' policy positions have a weaker effect on their ability to attract personal votes compared to their personal vote-earning attributes.

H3a: Candidates with party-median policy positions attract more personal votes. H3b: Candidates with policy positions that deviate from the party-median attract more personal votes.

\section{The Finnish OLPR}

This study is situated in one of the oldest examples of an open-list PR system, namely Finland. The Finnish OLPR is characterised by duality in terms of electoral competition, with a salient inter, as well as intraparty dimension. Finnish elections, like elections in most Western European countries, are fought between parties, and the allocation of seats across parties determines how power is distributed in the Parliament. The distinctive aspect of the Finnish system, certainly in comparison to most other PR systems, is that the fully open-list makes it impossible for parties to guarantee the election of any individual candidate, contributing to a high degree of intraparty competition. Alongside the competition over seats and vote shares between parties, candidates within the same party compete over the seats that the party will win collectively. 
In Finland, preferential voting is mandatory: to cast a vote all voters are obliged to choose one candidate from a large selection of aspirants, and they do so by writing the number of their preferred candidate on the ballot paper (Karvonen 2010). Given that most parties refrain from ranking their nominated candidates ${ }^{1}$, the sole criterion in determining the internal party ranking of candidates is the number of votes each candidate receives (Raynolds et al. 2005). By presenting candidates in alphabetical order on the lists, voters are left without an indication of parties' order of preference. All votes casted for individual candidates are however pooled at the party level, and the total amount of preference votes casted for a party (or a list in a district) determines how many seats the party wins (von Schoultz 2017).

Apart from the basic features of OLPR which include vote pooling at the list level and unranked lists, the Finnish electoral system has the following important features: the 200 seats in the Eduskunta (or Riksdagen in Swedish) are constitutionally distributed using the D'Hondt highest average method, in twelve to eighteen districts. In the 2015 election (included in this study), the number of districts was thirteen, and district magnitude (M) ranged from 1 to $35 .{ }^{2}$ No fixed electoral threshold or national tier is applied. Nomination procedures are regulated by law and decentralised (Karvonen 2014).

Parties are allowed to nominate a maximum of 14 candidates or, if $\mathrm{M}$ exceeds 14 , the number of representatives to be elected. Parties generally field full lists, which makes the system highly demanding for voters. In the largest-M constituency of Uusimaa, the total number of candidates in the 2015 election amounted to 395 , of which Uusimaa voters were required to single

\footnotetext{
${ }^{1}$ Nomination processes are decentralised in Finland and there is party internal variation in terms of the type of list applied. While ranking of candidates indeed is relatively rare, it occurs. In the 2015 election SDP was the only party that used ranked lists, and they did so in three districts.

${ }^{2}$ The only single member district is the Åland islands, located in the northern part of the Baltic Sea. For the mainland districts $\mathrm{M}$ is determined by the population and did in the 2015 election range from 7 to 35 .
} 
out one candidate for whom to cast their vote. The extensive number of candidates, and the individualised style of campaigning, implies that voters are overloaded with information to process, while receiving little guidance or indicative shortcuts from parties (von Schoultz 2016).

In comparison to other countries that use OLPR (such as Brazil, Colombia and Poland), Finland stands out as a consolidated, party-based democracy. In this respect, Finland resembles many other proportional electoral systems using closed or flexible lists. From the perspective of this study, a unique (to the best of our knowledge) empirical test of the extent to which policy positions contribute to individual electoral success, this is an important aspect to take into account, since the consolidated party system is in itself a clear signal that party platforms, policy stands and ideologies matter to electoral choices. Seen from this perspective, Finland can be considered as a critical case with favourable conditions, where one ought to expect policy positions to matter also for the candidates' ability to attract personal votes. Alternatively, if viewed from the perspective of other consolidated, party-based democracies with preferential voting systems and lower degrees of openness (so called flexible lists), such as the Belgian or Danish system, the Finnish case can be considered as a critical case with unfavourable conditions, where the policy positions of individual candidates are likely to matter less. This due to the highly complex context in which voters are forced to choose a single candidate, the absence of party cues regarding candidate choice, and the extensive amount of information regarding both individual candidates and parties present during the election campaign.

\section{Research design}

\section{Data}

This study utilises data from three sources. First, an extensive database including electoral and biographic data at the candidate level for all those nominated in the 2015 Finnish Parliamentary 
election combined with relevant data at the district and party level. ${ }^{3}$ The main sources used to gather data were official websites with electoral statistics, supplemented with information from other relevant sources when needed ${ }^{4}$.

Secondly, the data on candidates was merged with data on candidates' policy positions that were harvested via two voting advice applications (VAA) run by Finland's national public service broadcasting company $Y L E$, and the country's largest newspaper Helsingin Sanomat. All candidates nominated in the 2015 Parliamentary election were invited to participate in these two VAAs, were they responded to a series of statements regarding relevant and topical policy issues. For example, on matters such as social security, immigration, health, employment and taxation, candidates were asked to indicate their strength of agreement with these statements using an ordered scale from strong agreement to strong disagreement.

By merging all the aforementioned data a unique data set was created that contained information on candidates' personal characteristics and their policy positions. The merged file consisted of 2,161 candidates that were nominated by the seventeen political parties that contested the 2015 Finnish parliamentary elections. The analysis was however restricted to party lists that managed to win at least one seat, which left a total sample size of $\mathrm{N}=1,319$. More information on the variables is found in the Appendix (Appendix A).

\section{Variables and model specifications}

The dependent variable is the preference vote share of candidates, defined as the ratio of preference votes towards the total number of preference votes obtained in the district by all the candidates nominated by the same party. As Figure 1 demonstrates, the variable "preference vote share" has a skewed distribution, so our model specification assumes a multilevel generalised linear analysis

\footnotetext{
3 We thank Mattias Karlsson for excellent work on the data collection.

${ }^{4}$ The ministry of Justice (www.vaalit.fi) and statistics of Finland (www.tilastokeskus.fi).
} 
with a log link-function. The multilevel analysis is justified by the fact that candidates are nested within parties, and parties within (electoral) districts. Assuming both fixed and random effects where the intercept can vary in the level of party and district, three different models were specified. The first (Model 1), contained variables only related to candidates' policy positions, that is, the political message per se (the formula that is related to policy positions is considered in detail in the following section). The second (Model 2), contains variables related to the 'carrier' of the political message, that is, on the personal vote-earning attributes of candidates. Lastly, Model 3 integrated Model 1 and Model 2 meaning that it contained variables that assessed the role of both the carrier of the message (PVEA) and the message itself (policy positions).

[Figure 1 about here]

The PVEA included are individual-level dummy variables; a given candidate either has the attribute or does not. The PVEA binary variables are: (1) incumbency in the national parliament $(M P) ;(2)$ service on the local council of the municipality in which the candidate resides (local); (3) whether they were born in the municipality the candidate resides in (native); (4) whether, in the case of a non-MP, the candidate has a personal reputation from outside politics (celebrity); (5) education (primary and lower secondary/upper secondary vocational/upper secondary general/higher).

Included in the model we also have a set of controls: (6) gender (7) age and (8) age-square.

\section{Policy positions}

To develop appropriate measures for the policy positions of candidates derived from 52 issue statements we employed a polychoric correlation analysis. A few issues that were very marginal during the 2015 electoral campaign were excluded, which left 45 policy positions. Lastly, setting a strict, but widely accepted, criterion that the loadings should be $>.75$, an orthogonal rotation left 14 items that load on two dimensions, presented in Table 1. 
[Table 1 about here]

Eleven items load on the first dimension and include statements such as: "The duration of earnings-related unemployment benefit must be shortened"; "The economy of the state and municipalities must be balanced primarily by cutting spending"; "The public sector in Finland is too large and should be reduced"; "Health and social services must be primarily provided as public services". These items clearly revolve around social welfare, economic policies and public finance that are related to the traditionally dominant left-right dimension in Finnish politics (KestiläKekkonen et al. 2018).

Although issues such as unemployment benefits, taxation, health, social services and so on, always occupy the epicentre of discussions in countries with a prominent welfare state such as Finland, this was even more marked during the 2015 electoral campaign in the context of the ongoing recession. The second dimension tapped into the cultural issues which have become increasingly important in Finnish politics over the last decade (Westinen 2015). The three items that load on this dimension revolve around immigration; an issue that the xenophobic Finns Party have capitalized on, and used to increase its electoral share to become the second largest party nationwide.

After identifying these two dimensions, an index of weighted sum scores (WSS) was calculated by multiplying each loading with the score in each item, before summing up the product scores. Figure 2 gives a descriptive summary of the WSS of the first and second dimension for each party respectively, and also how the parties (and candidates) are positioned in this two-dimensional space. For visualisation purposes, the scores have been standardised.

[Figure 2 about here] 
Figure 2 provide a good overview of how the parties are positioned in the Finnish political landscape, and how cohesive they are on the two policy dimensions. The average scores on the left and right dimension of all candidates nominated for parties such as the Left Alliance (VAS), Green League (VIHR) and Social Democratic Party (SDP), are found to the left of zero (which equals the mean), while, a majority of the candidates running for the National Coalition Party (KOK), the Centre Party (KESK), the Swedish People's Party (RKP), the Christian Democrats (KD) and the Finns Party (PS), are found to the right of zero. This result makes for intuitive logic since VAS, VIHR and SDP are considered left-wing parties and therefore their candidates were expected to score low on items that advocate inter alia, the reduction of public services and cutting welfare benefits. Naturally, the converse ought to be the case for a right-wing party such as KOK, whose candidates were expected to score highly on such items. It is interesting to note that the scores for those candidates nominated for parties with a less distinct left-right identity, such as the Swedish Peoples Party (RKP) or the centrist-rightist (KESK) and the populist Finns Party (PS), are more dispersed than others.

The cultural dimension (D2) also demonstrates an expected pattern in the mean position and the distribution of candidates. Clearly, only two of the parties fielded candidates with a distinct and relatively coherent policy profile on the cultural dimension. At one end of the policy spectrum, it was found that the Finns Party (PS), whose candidates recorded the highest scores, demonstrated that they supported policies that seek to constrain immigration and limit the asylum process. At the other, supporting affirmative action on the immigration and asylum process, we find the Swedish Peoples Party (RKP), a party that represents the interests of the Swedish speaking minority in Finland. Candidates for the Left-Alliance (VAS) and the Greens (VIHR), lean towards the same policy space as RKP, but are slightly less coherent. For all other parties standardised WSS were close to zero and resemble a normal distribution. 
The general theme emerging from these descriptive statistics is that the two dimensions retrieved from the polychoric analysis grasp two relevant dimensions in Finnish politics and that the party label matters for the positions that candidates take. It is also clear however, that there is a great deal of variation on the intraparty dimension in terms of the policy positions candidates take. This is consistent with the expectation that candidates try to carve out a distinct profile by making programmatic appeals to set them apart from candidates nominated on the same list (Matakos et al. 2018; Shugart et al. 2005, Ames 1995).

Following we construct a linear measure of dimensional distance (LDD) that grasps how individual candidates relate to other candidates running for the same party:

$$
L D D=\left|\widetilde{W S} S_{c}-W S S_{i}\right|
$$

In (1) $\widetilde{W S} S_{c}$ is the median ${ }^{5}$ weighted sum score of all candidates $(C)$ running for a certain party, and $W S S_{i}$ is the weighted sum score of the individual candidate $i$, belonging to the same party. So, LDD is a measure of the distance from each candidate's weighted sum score in relation to the average weighted sum score of her/his co-partisans. For the purposes of comparison, the LDDs for each of the two-policy dimension were rescaled to range from 0-100 - thus where 0 indicates no distance from the median score of the co-partisans, 100 designates the maximum distance from the median score of the co-partisans.

\section{Analysis}

Following the above, the article now considers the tests applied to the previously outlined hypotheses concerning the electoral value of PVEA and policy positions, and how far voters reward

\footnotetext{
${ }^{5}$ We use the median instead of the mean since WSS is calculated based on answers on ordinal variables.
} 
candidates with party-moderate or party-extreme policy positions. Table 2 presents the coefficient estimates from a series of three multi-level mixed generalised linear models. Where Models 1 and 2 are simple models, that only include policy positions, and PVEA respectively alongside the control variables, Model 3 is a full model, including both policy positions, PVEA and control variables.

Model 1 shows the initial results regarding the effects of holding policy positions that deviate from those of co-partisans on the left-right dimension (LDD1), and the cultural dimension $(\mathrm{LDD} 2)^{6}$. The results from this first test, including only the policy dimensions and controls for gender, age and age-square, demonstrate that programmatic appeals have a modest, but nevertheless significant effect, on the electoral fortunes of candidates. The estimate of LDD1 is significant with $p=.009$ and with $p=.012$ for LDD2. The negative estimates indicate that the further from the partymedian score a candidate is positioned, the lower share of preference votes he or she is likely to win. The results hence allow us to verify hypothesis $3 \mathrm{a}$, while falsifying the competing hypothesis $3 b$.

[Table 2 about here]

The second model introduce the personal vote-earning attributes, i.e. the candidateidiosyncratic variables, which following previous research (e.g. Shugart et al. 2005; Tavits 2010; Put and Maddens 2015) have statistically significant effects on the electoral fortunes of candidates. Incumbent MPs or candidates that are elected at the municipal level (locals) are (unsurprisingly) more likely to be electorally successful compared to candidates that lack political experience. However, the electoral value of holding office at the national level, far outweigh the value of holding office at the local level. It is also found that candidates who are native to the municipality they reside in, are likely to receive a comparatively larger share of votes. In addition, the distinct

\footnotetext{
${ }^{6}$ The Pearson correlation of the two variables is as low as .2 .
} 
value of being well known from fields other than politics is reflected; celebrity status contribute to candidates winning a substantially greater proportion of the votes on the list. With regard to education, the estimates of both upper secondary and also upper vocational are negative and statistically significant, meaning that the preference vote share declines as candidates' education changes from higher to upper secondary and from higher to upper vocational. Model 2 hence allows us to verify hypothesis 1 , stating that personal vote-earning attributes increase candidates' ability to attract personal votes.

In Model 3, where the two sets of variables are combined, there is a clearer indication of the robustness of the findings. The coefficient estimates change little and most importantly continue to be statistically significant. In other words, this model confirms that three of our theoretically derived hypotheses hold up against the evidence. As expected and outlined in $\mathrm{H} 2$, it is found that the policy appeals candidates make contribute less to their electoral performance compared to personal attributes (PVEA) (see figure 3 below). We also find that candidates that take on partymoderate policy positions are more successful than those who positioned themselves far from the median position of their co-partisans (H3a). Perhaps less surprisingly, the model confirms that the personal vote-earning attributes of candidates related to expertise, localism and visibility, substantially contribute to their electoral fortunes (H1). The superiority of Model 3, characterised by the addition of variables related to programmatic appeals to Model 2, is demonstrated by a likelihood ratio test $\left(\operatorname{LR} \chi^{2}(2)=20.35, \mathrm{p}>\chi^{2}=0.000\right)$.

To check for the robustness of our findings we re-run our models including three additional variables. The first two variables control for the overall position of the candidate (candidatemedian) on the two policy dimensions. These are introduced to control for the possibility that it is not intra-party positions that matters, but rather the position of candidates compared to all other candidates on display, in line with the original model of proximity voting (Downs 1957). The third variable control for list position, since previous research has demonstrated that the order of 
candidates on the ballot causes (a weak) bias in election outcomes (e.g. Blom-Hansen, Elklit, Serritzlew and Villadsen, 2016). Results show that when we add these variables findings remain essentially the same as the ones reported in Table 2 (See online Appendix: Table X). Lastly, if one controls for the effect of aggregated variables in the list level, findings are also almost identical with the ones presented in Table 2 (See online Appendix: Table Z). ${ }^{7}$

For illustrative purposes, we present the margins of all PVEA and policy position variables included in the full model (Model 3). For the continuous variables "LDD1" and "LDD2" the scores that correspond to the first and last quartile are used as anchor points (however any percentile other than the $25^{\text {th }}$ and $75^{\text {th }}$ would do). The first quartile of "LDD1" ("LDD2") is at 6.32 (9.98), and the third one at $23.42(22.35)$.

[Figure 3 about here]

Figure 3 clearly demonstrates that not all variables included in the model hold an equal value in terms of vote winning. While party-moderate policy positions on behalf of candidates systematically contribute to increase their vote shares, the effects of such appeals are fairly modest and do not come close to the value of being an incumbent MP or a celebrity candidate. On average, the probability in vote shares decreases with $0.5 \%$ for candidates that move from the first (Q1) to the last quartile (Q3). This can be compared to an average increase in vote share probability of $13.8 \%$ when comparing non-incumbents with incumbents; whereas the average increase in probability when one moves from non-celebrity to celebrity candidates is $11.8 \%$. The PVEAs related to locality have more modest effects on vote winning, with expected increases in probability of $1.2 \%$ (native) and $1.5 \%$ (local incumbency) respectively.

\footnotetext{
${ }^{7}$ We thank an anonymous reviewer for these suggestions.
} 


\section{Concluding remarks}

This study analyse the link between candidates and voters by empirically exploring which factors contribute to the electoral success of candidates under the Finnish OLPR system. Our baseline expectation was that the representational link at the individual level mainly is constituted by personal characteristics, rather than by policy appeals; an expectation found in theories on decisionmaking strategies applied by voters when confronted with highly complex electoral settings (Lau and Redlawsk 2006). Our expectation was confirmed. The electoral fortunes of candidates are however not solely influenced by the personal vote-earning attributes they display, such as political experience, localism and celebrity status, but also by the policy positions they take; albeit with the former outweighing the latter in terms of electoral value.

In extenso, our findings do not speak in favour of mavericks (Tavits 2009), candidates that deviate from the party line and from their co-partisans, being more electorally successful. More precisely, we have demonstrated that voters reward candidates who make party-moderate policy positions; a finding more in line with the logic of the since long established proximity model of voting.

We would argue that the findings call for a slight re-evaluation of electoral systems with strong preferential voting and multimember districts on two accounts. First, the findings indicate that the representational link between voters and candidates is not as shallow as often assumed. Contrary to received wisdom, the link is found to be substantial in terms of policy. It is hence not based exclusively on easily grasped competence attributes, or limited to indirect proxies for parochial interests related to locality. Rather, even under highly complex settings, voters are able to use policy appeals to single out their preferred candidates. From the standpoint of representation, open-list PR thus performs better than is often assumed. It might be that the widespread introduction of voting advice applications during the election campaign facilitate a more sophisticated level of information processing by voters, making it easier to identify a suitable 
candidate. However, in order to demonstrate such effects, we would need data that allow for the tracking of changes over time. Secondly, the behaviour of voters clearly does not contribute to disunity within parties, an often-emphasised negative characteristic of preferential voting systems. While our descriptive analyses indeed confirm that parties for vote-winning purposes tend to field candidates with diverse policy positions (or that candidates take on extreme positions in order to carve out a distinct profile), voters do not reward such behaviour. This may well be a contributory factor to the high level of intraparty voting cohesion observed in the Finnish Eduskunta (Pajala 2013). 


\section{References}

Ames B (1995) Electoral Strategy under Open-List Pro- Proportional Representation. American Journal of Political Science 39(2): 406-433

André A and Depauw S (2014) District Magnitude and the Personal Vote. Electoral Studies 35: 102-114.

André A, Depauw S and Deschouwer K (2014) Legislators' Local Roots: Disentangling the Effect of District Magnitude. Party Politics 20(6): 904-917.

André A, Depauw S Shugart MS and Chytilek R (2017) Party Nomination Strategies in FlexibleList Systems: Do Preference Votes Matter? Party Politics 23(5): 589-600.

Arter D (2009) Clowns, 'Alluring Ducks' and 'Miss Finland 2009': The Value of 'Celebrity Candidates' in an Open List PR Voting System. Representation 50(4): 453-470.

Arter D (2013) The 'Hows', not the 'Whys' or the 'Wherefores': The Role of Intra-party competition in the 2011 Breakthrough of the True Finns. Scandinavian Political Studies 36(2): 99-120.

Bergman ME, Shugart MS and Watt KA (2013) Patterns of Intraparty Competition in Open-Lists and SNTV Systems. Electoral Studies 32(2): 321-333.

Berggren N, Jordahl H and Poutvaara P (2010) The Looks of a Winner: Beauty and Electoral Success. Journal of Public Economics 94(1-2): 8-15.

Blais A, Nadeau R, Gidengil E and Nevitte N (2001) The formation of party preferences: testing the proximity and directional models. European Journal of Political Research 40(1): 81-91.

Blom-Hansen J, Elklit J, Serritzlew S and Villadsen LR (2016) Ballot Position and Election Results: Evidence From a Natural Experiment. Electoral Studies 44: 172-183.

Butler DM (2009) A Regression Discontinuity Design Analysis of the Incumbency Advantage and Tenure in the U.S. House. Electoral Studies 28(1): 123-128.

Carey JM (2007) Competing Principals, Political Institutions, and Party Unity in Legislative Voting. American Journal of Political Science 51(1): 92-107.

Carey JM and Shugart MS (1995) Incentives to Cultivate a Personal Vote. Electoral Studies 14(4): 417-439

Cain B, Ferejohn J, and Fiorina M (1987). The Personal Vote: Constituency Service and Electoral Independence. Cambridge: Harvard University Press.

Carozzi F and Repetto L (2016) Sending the Pork Home: Birth Town Bias in Transfers to Italian Municipalities. Journal of Public Economics 134, 42-52. 
Colomer J (2011) Personal Representation: The Neglected Dimension of Electoral Systems. Essex: ECPR Press.

Carson JL, Engstrom EJ and Roberts JM (2007) Candidate Quality, the Personal Vote, and the Incumbency Advantage in Congress. American Political Science Review 101(2):289-301. Cox G (1990) Centripetal and Centrifugal Incentives in Electoral Systems. American Journal of Political Science 34(4): 903-935.

Crisp BF, Jensen KM and Yawel S (2007) Magnitude and Vote Seeking. Electoral Studies 26(4): $727-734$.

Crisp BF, Olivella S, Malecki M and Sher M (2013) Vote-Earning Strategies in Flexible List Systems: Seats at the Price of Unity. Electoral Studies 32(4): 658-669.

Dahlgaard OJ (2016) You Just Made It: Individual Incumbency Advantage under Proportional Representation. Electoral Studies 44: 319-328.

Downs A (1957) An economic theory of democracy. New York: Harper Collins.

Erikson R (1971) The Advantage of Incumbency in Congressional Elections. Polity 3(3): 395405.Gelman A and King G (1990) Estimating the Incumbency Advantage without Bias. American Journal of Political Science 34(4): 1142-1164.

Grofman B (2008) The Impact of Electoral Laws on Political Parties. In Wittman DA and Weingast BR (eds) The Oxford Handbook of Political Economy. Oxford: Oxford University Press, 102-121.

Hix S (2004) Electoral Institutions and Legislative Behaviour: Explaining Voting Defection in the European Parliament. World Politics 56(1): 194-223.

Horiuchi Y, Smith D M and Yamamoto T (n.d.) Identifying voter preferences for politicians' personal attributes: a conjoint experiment in Japan. Political Science Research and Methods 1-17. doi:10.1017/psrm.2018.26

Karvonen L (2010) The Personalisation of Politics. A study of Parliamentary Democracies. Colchester: ECPR Press.

Karvonen L (2014) Parties, Governments and Voters in Finland. Politics under Fundamental Societal Transformation. Colchester: ECPR Press.

Key, V. O., Jr. (1949). Southern politics in state and nation. New York: A.A. Knopf.

Kitschelt H and Smyth R (2002) Programmatic Party Cohesion in Emerging Postcommunist Democracies Russia in Comparative Context. Comparative Political Studies 35(10): 1228 1256. 
Kotakorpi K, Poutvaara P and Terviö M (2017) Returns to Office in National and Local Politics: A Bootstrap Method and Evidence from Finland. The Journal of Law, Economics and Organization 33(3): 413-442.

Lau RR and Redlawsk DP (2006) How Voters Decide. Information Processing During Election Campaigns. New York, NY: Cambridge University Press.

Maddens B, Wauters B, Noppe J and Fiers S (2006) Effects of Campaign Spending in an Open List PR System: The 2003 Legislative Election in Flanders/Belgium. West European Politics 29(1): 161-168.

Matakos K, Savolainen R, Troumpounis O, Tukiainen J and Xefteris D (2018) Electoral Institutions and Intra-party Organization. Working Paper VATT Institute for Economic Research.

Meriläinen J and Tukiainen J (2018) Rank Effects in Political Promotions. Public Choice 177(1-2): 87-109.

Mondak JJ (1993) Public Opinion and Heuristic Processing of Source Cues. Political Behavior 15(2): 167-192.

Pajala A (2013) Government vs Opposition Voting in the Finnish Parliament Eduskunta since World War II. European Journal of Government and Economics 2(1): 41-58.

Popkin SL (1991) The Reasoning Voter: Communication and Persuasion in Presidential Campaigns. Chicago: Chicago University Press

Put GJ and Maddens B (2015) The Effect of Municipal Size and Local Office on the Electoral Success of Belgian/Flemish Election Candidates: A Multilevel Analysis. Government and Opposition 59(4): 607-628.

Rabinowitz G and Macdonald SE (1989) A directional theory of issue voting. American Political Science Review 83(1): 93-121.

Raynolds A, Ben R and Andrew E (2005) Electoral System Design: The New International IDEA Handbook. International Institute for Democracy and Electoral Assistance.

Saarimaa T and Tukiainen J (2016) Local Representation and Strategic Voting: Evidence from Electoral Boundary Reforms. European Journal of Political Economy 41: 31-45.

von Schoultz $\AA$ (2016) Passing through the Eye of the Needle- Individual Electoral Success in Finnish Parliamentary Elections. In Karvonen L, Paloheimo H and Raunio T (eds) The Changing Balance of Political Power in Finland. Stockholm: Santerus Academic Press, 163-188. von Schoultz Å (2017) Electoral Systems in Context: Finland. In Herron ES, Pekkanen RJ and Shugart MS (eds.), Oxford Handbook of Electoral Systems. Oxford: Oxford University press, 601-626. 
Shugart MS, Valdini ME and Suominen K (2005) Looking for Locals: Voter Information Demands and Personal Vote-Earning Attributes of Legislators under Proportional Representation. American Journal of Political Science 49(2): 437-449.

Singh SP (2010) Contextual influences on the decision calculus: A cross-national examination of proximity voting. Electoral Studies 29(3): 425-434.

Tavits M (2009) The Making of Mavericks: Local loyalties and party defection. Comparative Political Studies 20(10): 1-23.

Tavits M (2010) Effect of Local Ties on Electoral Success and Parliamentary Behaviour. The Case of Estonia. Party Politics 16(2): 215-235.

Valdini ME (2006) Electoral institutions and information shortcuts: the effect of decisive intraparty competition on the behavior of voters and party elites. Thesis. UC San Diego. https://escholarship.org/uc/item/8718h6gc.

Westinen J (2015) Cleavages in contemporary Finland: A study on party-voter Ties. Åbo: Åbo Akademi University Press. 
Figure 1. Histogram of preference vote shares

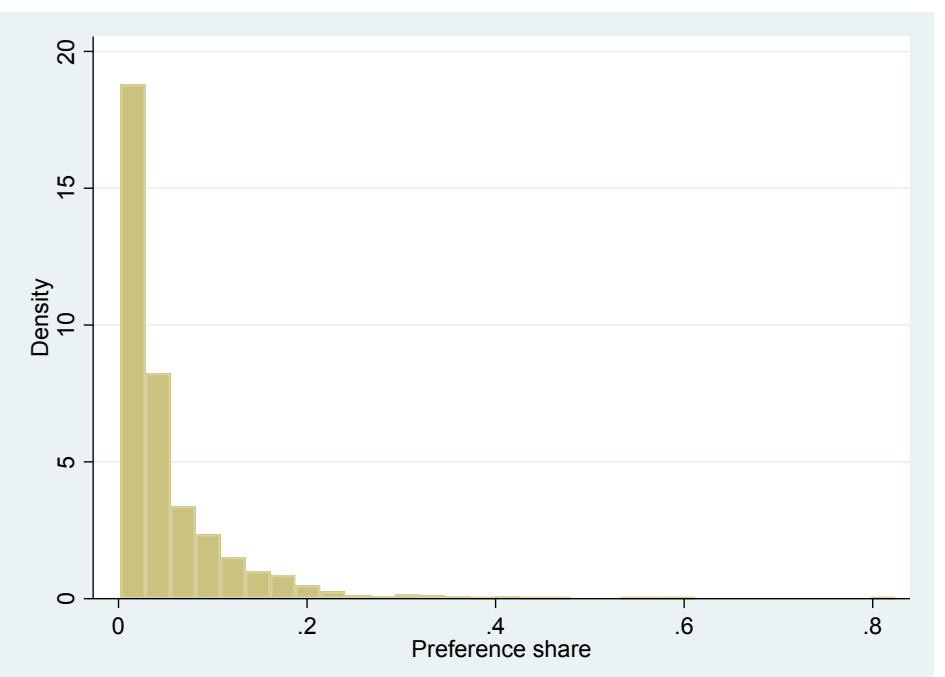

21 
Table 1. Factors and loadings from a polychoric analysis

\begin{tabular}{|c|c|c|}
\hline & Dimension 1 & Dimension 2 \\
\hline $\begin{array}{l}\text { "National law must ensure that labour contracts guarantee a minimum number } \\
\text { of working hours for employee" (r) }\end{array}$ & 0.76 & \\
\hline "The duration of earnings-related unemployment benefit must be shortened" & 0.76 & \\
\hline $\begin{array}{l}\text { "The economy of the state and municipalities must be balanced primarily by } \\
\text { cutting spending" }\end{array}$ & 0.75 & \\
\hline "Health and social services must be primarily provided as public services" (r) & 0.81 & \\
\hline $\begin{array}{l}\text { "Finland's public debt needs to be reduced even if this means cuts in services } \\
\text { and benefits" }\end{array}$ & 0.82 & \\
\hline "The public sector in Finland is too large and needs to be reduced" & 0.79 & \\
\hline $\begin{array}{l}\text { "Companies should be able to pay lower wages than agreed in collective } \\
\text { bargaining in order to increase employment" }\end{array}$ & 0.80 & \\
\hline "More public services should be outsourced to private companies" & 0.83 & \\
\hline $\begin{array}{l}\text { "If there is a situation where it is necessary either to cut public services and } \\
\text { social benefits or to raise taxes, the tax increase is a better option" (r) }\end{array}$ & 0.82 & \\
\hline $\begin{array}{l}\text { "High income differences are acceptable in order to reward differences in } \\
\text { people's talents and diligence" }\end{array}$ & 0.75 & \\
\hline $\begin{array}{l}\text { "Current services and social benefits are too burdensome for public finances in } \\
\text { the long-term" }\end{array}$ & 0.78 & \\
\hline "Immigration into Finland must be restricted because of the threat of terrorism" & & 0.81 \\
\hline "Finland should take on more responsibility for the asylum seekers entering the & & 0.81 \\
\hline EU” (r) & & \\
\hline "If the state provides the means for the establishment of a reception centre for & & 0.77 \\
\hline
\end{tabular}

Notes: (r) stands for reversed scale 
Figure 2. Average standardized WSS by party for the left-right dimension (D1), the cultural dimension (D2), and combined into a two-dimensional space.

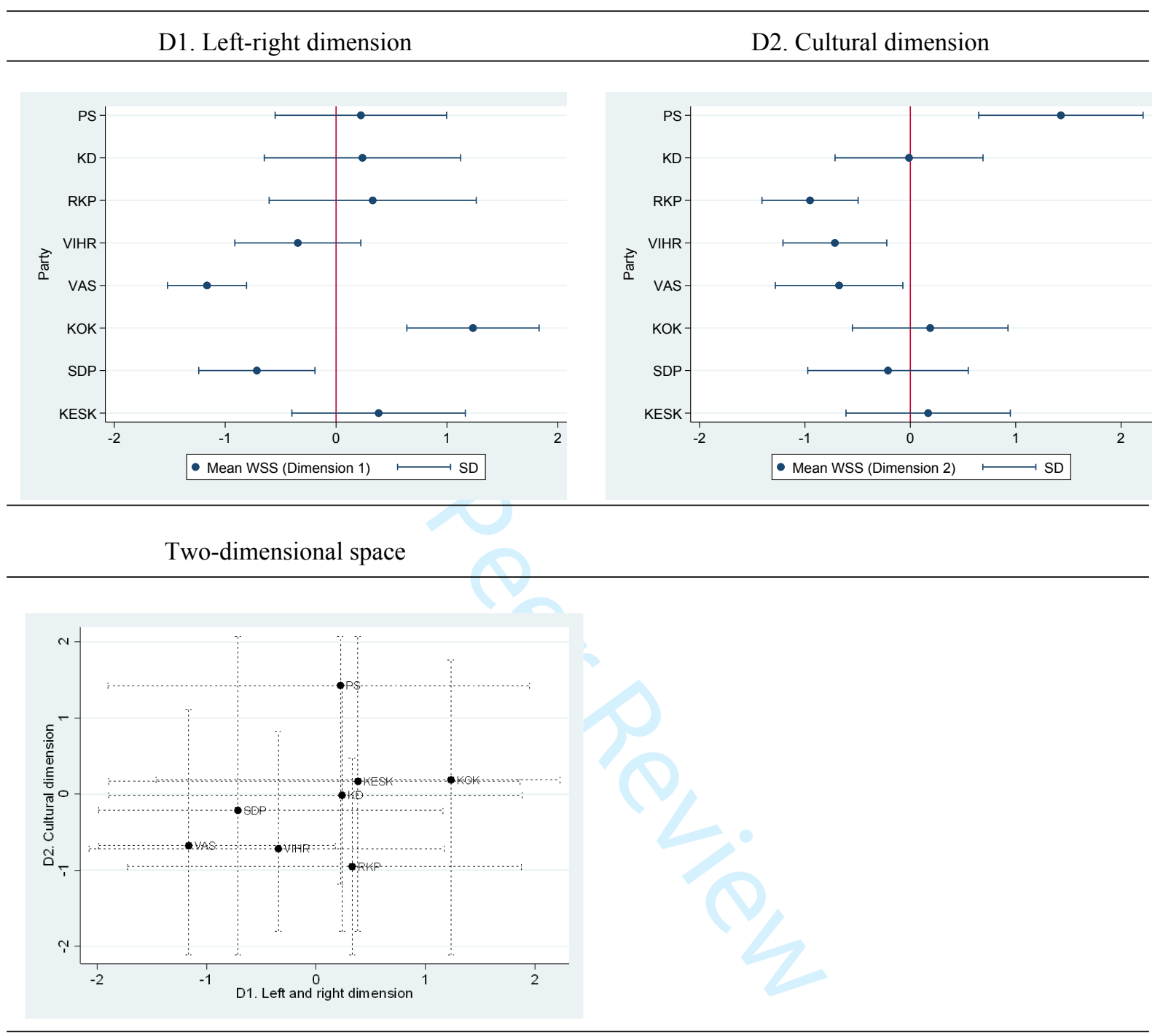


Table 2. Multilevel mixed generalised linear models (log link-function)

\begin{tabular}{|c|c|c|c|c|c|c|}
\hline \multirow{2}{*}{$\begin{array}{l}\text { Variables }^{1} \\
\text { Left-right, LDD1 (0-100) }\end{array}$} & \multicolumn{2}{|l|}{ Model 1} & \multicolumn{2}{|l|}{ Model 2} & \multicolumn{2}{|l|}{ Model 3} \\
\hline & $-.007 * *$ & $(.003)$ & & & $-.004 *$ & $(.002)$ \\
\hline Cultural, LDD2 (0-100) & $-.006^{*}$ & $(.003)$ & & & $-.007 * *$ & $(.002)$ \\
\hline MP (d) & & & $1.441 * * *$ & $(.064)$ & $1.413^{* * *}$ & $(.063)$ \\
\hline Local (d) & & & $.278^{* * *}$ & $(.070)$ & $.246^{* * *}$ & $(.070)$ \\
\hline Native (d) & & & $.195^{* *}$ & $(.059)$ & $.183^{* *}$ & $(.058)$ \\
\hline Celebrity (d) & & & $1.241 * * *$ & $(.116)$ & $1.119^{* * *}$ & (.112) \\
\hline \multicolumn{7}{|l|}{ Education (ref. higher edu): } \\
\hline Primary and lower secondary & & & -.311 & $(.340)$ & -.188 & $(.322)$ \\
\hline Upper secondary vocational & & & $-.346^{* * *}$ & $(.079)$ & $-.344 * * *$ & $(.079)$ \\
\hline Upper secondary general & & & $-.443 * * *$ & $(.121)$ & $-.461 * * *$ & $(.121)$ \\
\hline Gender (female) (d) & .093 & $(.068)$ & $.265 * * *$ & $(.056)$ & $.214 * * *$ & $(.056)$ \\
\hline Age & $.059 * *$ & $(.022)$ & $.057 * *$ & $(.020)$ & $.050 * *$ & $(.019)$ \\
\hline $\mathrm{Age}^{2}$ & $-.001 *$ & $(.000)$ & $-.001 * *$ & $(.000)$ & $-.001 * *$ & $(.000)$ \\
\hline $\mathrm{N}$ & 1,294 & & 1,078 & & 1,078 & \\
\hline \multirow[t]{2}{*}{ LR test vs. flat model } & \multicolumn{2}{|c|}{$\chi^{2}(01)=38.85$} & \multicolumn{2}{|c|}{$\chi^{2}(2)=183.67$} & \multicolumn{2}{|c|}{$\chi^{2}(2)=193.22$} \\
\hline & \multicolumn{2}{|c|}{ Prob $>\chi^{2}=0.000$} & \multicolumn{2}{|c|}{ Prob $>\chi^{2}=0.000$} & \multicolumn{2}{|c|}{ Prob $>\chi^{2}=0.000$} \\
\hline \multicolumn{7}{|l|}{ Random effects parameters: } \\
\hline District level: Var (Constant) & .051 & $(.026)$ & .105 & $(.060)$ & .095 & $(.055)$ \\
\hline Party level: Var (Constant) & $1.35 \mathrm{e}-36$ & $(1.1 \mathrm{e}-19)$ & .213 & $(.053)$ & .194 & (.049) \\
\hline
\end{tabular}

Notes: In Model 1 the hierarchical model differs from the flat only with respect to the variance component; Reference categories: 'Higher education' (Education); 'Male' (Gender); for all other dummies (d), 0 stands for 'No' and 1 for 'Yes'; $* * * \mathrm{p}<0.001, * * \mathrm{p}<0.01,{ }^{*} \mathrm{p}<0.05$, Alpha $=0.05$.

\footnotetext{
${ }^{1}$ Descriptive statistics of the variables are given in online Table V.
} 
Figure 3. Predictive margins with $95 \% \mathrm{CI}$
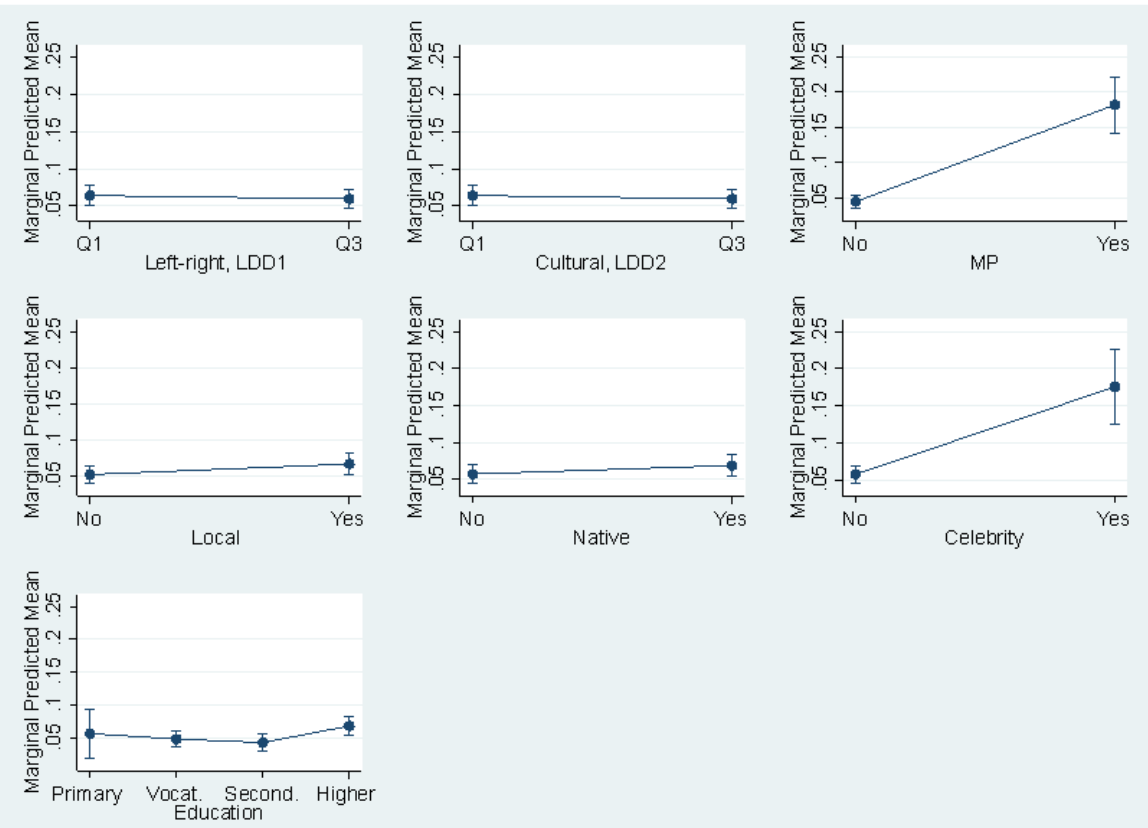
Online Table V

\begin{tabular}{lcc}
\hline Variables & $\mathrm{N}$ & Mean \\
\hline Left-right, LDD1 (0-100) & 1,343 & 18.280 \\
Cultural, LDD2 (0-100) & 1,341 & 17.987 \\
MP & & \\
(0) No & 1,200 & .886 \\
(1) Yes & 154 & .114 \\
Local & & \\
(0) No & 556 & .411 \\
(1) Yes & 798 & .589 \\
Native & & \\
(0) No & 816 & .611 \\
(1) Yes & 519 & .389 \\
Celebrity & & \\
(0) No & 1,313 & .970 \\
(1) Yes & 41 & .030 \\
Education: & & .019 \\
(1) "Primary and lower secondary" & 21 & .196 \\
(2) "Upper secondary vocational" & 220 & .098 \\
(3) "Upper secondary general" & 110 & .688 \\
(4) "Higher education" & 774 & .549 \\
Gender & & .451 \\
(0) Male & 744 & 45.228 \\
(1) Female & 610 & $2,196.806$ \\
Age & 1,354 & \\
Age & 1,354 & \\
\hline
\end{tabular}


Online Table X. Multilevel mixed generalised linear models (log link-function) controlling for measures of overall centrality and list position

\begin{tabular}{|c|c|c|c|c|c|c|}
\hline \multirow{2}{*}{$\begin{array}{l}\text { Variables } \\
\text { Left-right, LDD1 (0-100) }\end{array}$} & \multicolumn{2}{|l|}{ Model 1} & \multicolumn{2}{|l|}{ Model 2} & \multicolumn{2}{|l|}{ Model 3} \\
\hline & $-.007 * *$ & $(.003)$ & & & $-.005^{*}$ & $(.002)$ \\
\hline Cultural, LDD2 (0-100) & $-.007 * *$ & $(.003)$ & & & $-.006^{* *}$ & $(.002)$ \\
\hline MP (d) & & & $1.470 * * *$ & $(.065)$ & $1.441 * * *$ & $(.064)$ \\
\hline Local (d) & & & $.305^{* * *}$ & $(.071)$ & $.274 * * *$ & $(.071)$ \\
\hline Native (d) & & & $.188 * *$ & $(.059)$ & $.172 * *$ & $(.058)$ \\
\hline Celebrity (d) & & & $1.206^{* * *}$ & $(.111)$ & $1.088 * * *$ & $(.111)$ \\
\hline $\begin{array}{l}\text { Measure of overall centrality } \\
\text { for Left-right dimension }\end{array}$ & .000 & $(.002)$ & & & .003 & $(.003)$ \\
\hline $\begin{array}{l}\text { Measure of overall centrality } \\
\text { for Cultural dimension }\end{array}$ & -.001 & $(.001)$ & & & -.001 & $(.002)$ \\
\hline List position & $-1.290 * *$ & $(.394)$ & $-.733^{*}$ & $(.318)$ & $-.735^{*}$ & $(.313)$ \\
\hline List position ${ }^{2}$ & $1.152 * *$ & $(.386)$ & .471 & $(.315)$ & .488 & $(.313)$ \\
\hline Education (ref. higher edu): & & & & & & \\
\hline Primary and lower secondary & & & -.252 & $(.335)$ & -.140 & $(.319)$ \\
\hline Upper secondary vocational & & & $-.345 * * *$ & $(.079)$ & $-.328 * * *$ & $(.079)$ \\
\hline Upper secondary general & & & $-.442 * * *$ & $(.120)$ & $-.444 * * *$ & $(.119)$ \\
\hline Gender (female) (d) & .094 & $(.068)$ & $.270 * * *$ & $(.056)$ & $.218 * * *$ & $(.056)$ \\
\hline Age & $.057 * *$ & $(.022)$ & $.053 * *$ & $(.020)$ & $.048 *$ & $(.019)$ \\
\hline $\mathrm{Age}^{2}$ & $-.001 *$ & $(.000)$ & $-.001 * *$ & $(.000)$ & $-.001 * *$ & $(.000)$ \\
\hline $\mathrm{N}$ & 1,294 & & 1,078 & & 1,078 & \\
\hline \multirow[t]{2}{*}{ LR test vs. flat model } & \multicolumn{2}{|c|}{$\chi^{2}(01)=36.46$} & \multicolumn{2}{|c|}{$\chi^{2}(2)=195.50$} & \multicolumn{2}{|c|}{$\chi^{2}(2)=202.53$} \\
\hline & \multicolumn{2}{|c|}{ Prob $>\chi^{2}=0.000$} & \multicolumn{2}{|c|}{ Prob $>\chi^{2}=0.000$} & \multicolumn{2}{|c|}{ Prob $>\chi^{2}=0.000$} \\
\hline \multicolumn{7}{|l|}{ Random effects parameters: } \\
\hline District level: Var (Constant) & .047 & $(.025)$ & .102 & $(.060)$ & .086 & $(.053)$ \\
\hline Party level: Var (Constant) & $4.18 \mathrm{e}-36$ & $(2.54 \mathrm{e}-19)$ & .227 & $(.056)$ & .219 & $(.055)$ \\
\hline
\end{tabular}

Notes: In Model 1 the hierarchical model differs from the flat only with respect to the variance component; Reference categories: 'Higher education' (Education); 'Male' (Gender); for all other dummies (d), 0 stands for 'No' and 1 for 'Yes'; *** $p<0.001,{ }^{* *} \mathrm{p}<0.01$, ${ }^{*} \mathrm{p}<0.05$, Alpha $=0.05$. 
Online Table Z. Multilevel mixed generalised linear models (log link-function) controlling for measures of overall centrality and cumulative list level variables

\begin{tabular}{|c|c|c|c|c|c|c|}
\hline \multirow{2}{*}{$\begin{array}{l}\text { Variables } \\
\text { Left-right, LDD1 (0-100) }\end{array}$} & \multirow{2}{*}{$\begin{array}{l}\text { Model } 1 \\
-.007^{* *}\end{array}$} & \multirow[b]{2}{*}{$(.003)$} & \multirow[t]{2}{*}{ Model 2} & \multicolumn{3}{|c|}{ Model 3} \\
\hline & & & & & $-.008^{* *}$ & $(.003)$ \\
\hline Cultural, LDD2 (0-100) & $-.006^{*}$ & $(.003)$ & & & $-.006^{* *}$ & $(.002)$ \\
\hline MP (d) & & & $1.455^{* * *}$ & $(.064)$ & $1.431 * * *$ & $(.063)$ \\
\hline Local (d) & & & $.280^{* * *}$ & $(.069)$ & $.262^{* * *}$ & $(.069)$ \\
\hline Native (d) & & & $.200 * *$ & $(.058)$ & $.187 * *$ & $(.058)$ \\
\hline Celebrity (d) & & & $1.194 * * *$ & $(.116)$ & $1.125^{* * *}$ & $(.110)$ \\
\hline Measure of overall centrality & .000 & $(.002)$ & & & $.006^{*}$ & $(.003)$ \\
\hline \multicolumn{7}{|l|}{ for Left-right dimension } \\
\hline Measure of overall centrality & -.001 & $(.002)$ & & & -.001 & $(.002)$ \\
\hline \multicolumn{7}{|l|}{ for Cultural dimension } \\
\hline \multicolumn{7}{|l|}{ Education (ref. higher edu): } \\
\hline Primary and lower secondary & & & -.311 & $(.335)$ & -.184 & $(.319)$ \\
\hline Upper secondary vocational & & & $-.366 * *$ & $(.078)$ & $-.359 * * *$ & $(.079)$ \\
\hline Upper secondary general & & & $-.463 * * *$ & $(.122)$ & $-.464 * * *$ & $(.120)$ \\
\hline Gender (female) (d) & .092 & $(.068)$ & $.262^{* * *}$ & $(.056)$ & $.215^{* * *}$ & $(.055)$ \\
\hline Age & $.061 * *$ & $(.023)$ & $.056^{* *}$ & $(.020)$ & $.051^{* *}$ & $(.019)$ \\
\hline $\mathrm{Age}^{2}$ & $-.001 *$ & $(.000)$ & $-.001 * *$ & $(.000)$ & $-.001 * *$ & $(.000)$ \\
\hline \multicolumn{7}{|c|}{ Cumulative list level variables } \\
\hline Sum age $\times 10^{-3}$ & .003 & $(.028)$ & .077 & $(.270)$ & -.231 & $(.303)$ \\
\hline Sum gender & -.003 & $(.003)$ & .022 & $(.017)$ & $.049^{*}$ & $(.020)$ \\
\hline Sum MPs & & & .008 & $(.055)$ & .095 & $(.066)$ \\
\hline Sum local & & & -.003 & $(.007)$ & -.012 & $(008)$ \\
\hline Sum native & & & -.009 & $(.007)$ & -0.109 & $(.007)$ \\
\hline Sum celebrity & & & -.054 & $(.091)$ & -.205 & $(.110)$ \\
\hline Sum education & & & -.003 & $(.001)$ & -.003 & $(.001)$ \\
\hline $\mathrm{N}$ & 1,294 & & 1,078 & & 1,078 & \\
\hline
\end{tabular}




\begin{tabular}{|c|c|c|c|c|c|}
\hline \multirow[t]{2}{*}{ LR test vs. flat model } & $\chi^{2}(01)=38.54$ & \multicolumn{2}{|c|}{$\chi^{2}(2)=161.01$} & \multicolumn{2}{|c|}{$\chi^{2}(2)=176.55$} \\
\hline & Prob $>\chi^{2}=0.000$ & \multicolumn{2}{|c|}{ Prob $>\chi^{2}=0.000$} & \multicolumn{2}{|c|}{ Prob $>\chi^{2}=0.000$} \\
\hline \multicolumn{6}{|l|}{ Random effects parameters: } \\
\hline District level: Var (Constant) & $(.028)$ & .148 & $(.074)$ & .134 & $(.067)$ \\
\hline Party level: Var (Constant) & $2.48 \mathrm{e}-37 \quad(4.18 \mathrm{e}-20)$ & .100 & $(.032)$ & .099 & $(.030)$ \\
\hline
\end{tabular}

Notes: In Model 1 the hierarchical model differs from the flat only with respect to the variance component; Reference categories: 'Higher education' (Education); 'Male' (Gender); for all other dummies (d), 0 stands for 'No' and 1 for 'Yes'; ${ }^{* * *} \mathrm{p}<0.001,{ }^{* *} \mathrm{p}<0.01$, ${ }^{*} \mathrm{p}<0.05$, Alpha $=0.05$; 